\title{
Expression of CD44 and IL-10 in normotensive and preeclamptic placental tissue
}

\author{
Mehmet Obut(), Süleyman Cemil Oğlak@i) \\ Department of Obstetrics and Gynecology, Health Sciences University, Diyarbakır Gazi Yaşargil Training and Research Hospital, \\ Diyarbakır, Turkey
}

\begin{abstract}
Objectives: We aimed to demonstrate cell-cell adhesion and apoptotic changes in preeclamptic placentas by examining the expression of CD44 and IL-10.

Material and methods: Placenta samples of 15 preeclamptic and 15 healthy 35-38th week-pregnant women were involved in the study. Tissue samples were taken only from the maternal side of the placenta and fixed in $10 \%$ formaldehyde, then blocked in paraffin wax and $5 \mu \mathrm{m}$-thick sections were cut and stained with Masson Trichrome. Antigen retrieval was performed for sections, incubated with CD44 antibody and anti-IL-10 antibody. After the application of streptavidin peroxidase followed by AEC chromogen solution, sections were counterstained with Mayer hematoxylin.

Results: In the preeclampsia group, increased CD44 positive expression was observed in maternal decidua cells and fibroblast cells close to root villi. CD44 was positively expressed in muscle cells around the blood vessels, mucosal connective tissue areas, syncytial nodes, and syncytial bridges. In the preeclampsia group, significant increased IL-10 expression was seen in subendothelial layers of the medium-sized vessels in the maternal region. IL-10 was also positively expressed in decidua cells outside the vessels, and inflamed connective tissue areas, chorionic villus cells with intense inflammation in intervillous spaces.

Conclusions: CD44 was found to be an essential molecule in the regulation of vascular permeability, inflammatory response, activation of the cells, cell-to-cell interaction, and the signaling pathways to which they are associated. Since IL-10 regulates appropriate pregnancy outcomes and contributes to the balance of anti-inflammatory signals via both paracrine and autocrine regulators of trophoblast activity, we proposed that it might be a key to elucidate the etiology of preeclampsia with CD44 receptor.
\end{abstract}

Key words: CD44; IL-10; normotensive and preeclampsia; placenta

Ginekologia Polska 2020; 91, 6: 334-341

\section{INTRODUCTION}

Preeclampsia, a complication of pregnancy, occurs in $5-8 \%$ of pregnancies. Preeclampsia, which is among the hypertensive diseases of pregnancy, is one of the causes of maternal deaths all around the world [1]. Preeclampsia is diagnosed by onset of new hypertension and proteinuria after $20^{\text {th }}$ week of gestation. In the absence of proteinuria, preeclampsia can be diagnosed with hypertension accompanying by evidence of systemic disease (such as elevated of liver enzyme or thrombocytopenia) [2]. Preeclampsia is a risk factor for complications such as maternal renal failure, liver involvement, organ dysfunction, uteroplacental insufficiency, fetal growth retardation. Insufficiency of trophoblastic invasion of the placenta is important in the pathophysiology of preeclampsia. Changes in the spiral ar- teries are impaired in preeclampsia, cause placenta hypoxia, and decreased fetal blood circulation [3].

The cause of maternal clinical symptoms in preeclampsia is systemic endothelial dysfunction. Endothelium-dependent vascular tone control and vasoconstriction lead to hypertension; increased capillary permeability leads to loss of fluid into the third cavity, hemoconcentration and edema; increased glomerular permeability leads to proteinuria and coagulation mechanism leads to extensive intravascular coagulation. In preeclamptic patients, inadequate migration and invasion of cytotrophoblasts prevent formation of normal physiological changes in the spiral arteries, or they are confined to only decidua part of the spiral arteries $[2,4,5]$.

Endothelial cells, trophoblasts and the immune cells in the endometrium during the implantation can synthesize 
many cytokines. A disorder in the cytokine environment may cause problems in the formation of placenta or may cause wide endothelial dysfunction, eventually leading to the development of preeclampsia [6].

Hyaluronic acid $(\mathrm{HA})$ is a repeating non-sulfated glycosaminoglycan polymer of recurrent disaccharide units of $\mathrm{N}$-acetyl glucosamine and p-gluconic acid. HA is an important component of extracellular matrix (ECM) of especially fast growing and remodeling tissues and plays a role in a variety of cellular functions including differentiation and inflammation [7].

CD44 mediates cell-to-cell and cell-to-matrix interactions through the hyaluronic acid $(\mathrm{HA})$ receptor. It also plays an important role in cell adhesion and migration, tumor growth and progression via HA [8]. Apart from HA, CD44 has affinity and other ligands, such as osteopontin, collagen and matrix metalloproteinases (MMPs).

$\mathrm{IL}-10$ is the main regulator of the inflammatory process and is present as a major immunomodulatory agent in the feto-maternal interface. The trophoblasts [9], decidua macrophages [10], natural killer (NK) cells [11] produce IL-10. It is most expressed at the feto-maternal interface of the extra villous cytotrophoblasts during the early pregnancy and villous cytotrophoblasts in late pregnancy [7]. Human leukocyte antigen (HLA-G) expression is inhibited lysis of maternal NK cells and induced by IL-10, which contributes to fetal allograft tolerance [12]. IL-10 also increases the resistance of trophoblasts to Fas-mediated apoptosis [13]. In our study, we aimed to demonstrate cell-cell adhesion and apoptotic changes in preeclamptic placentas.

\section{MATERIAL AND METHODS}

The study was approved by the Medical Committee of Diyarbakir Maternity and Child Health Hospital. All protocols were approved by local ethics committee. All patients were informed and signed consent form. All placenta tissues were provided from the Diyarbakır Maternity and Child Health Hospital (Department of Obstetrics and Gynecology). The study included 15 pregnant patients with placenta previa and 15 healthy pregnant patients between gestational age. Preeclampsia criteria were defined by hypertension (systolic blood pressure $\geq 140 \mathrm{mmHg}$ and/or diastolic blood pressure $\geq 90 \mathrm{mmHg}$ ) and proteinuria (> $300 \mathrm{mg}$ in $24 \mathrm{~h}$ ). Clinical blood tests were gathered and experimental biochemical analysis were performed on blood samples of patients. The placental tissues were immersed in $10 \%$ buffered formaldehyde. They were dehydrated in ascending alcohol series, cleaned in xylene and embedded in paraffin. Then $4 \mu \mathrm{m}$ sections were cut and stained with Trichrom Masson.

\section{Immunohistochemical examination}

All sections were bought to distilled water and for further immunohistochemical examination. Antigen retrieval process was performed in citrate buffer solution $(\mathrm{pH}: 6.0)$ for 10 minutes in a microwave oven at $700 \mathrm{~W}$. Sections were permitted to cool down at room temperature for 30 minutes and washed in distilled water $2 \times 5$ minutes. $3 \%$ hydrogen peroxide $\left(\mathrm{H}_{2} \mathrm{O}_{2}\right)$ was used for endogen peroxidase blocking for 10 minutes. Samples were rinsed in distilled water and washed in PBS. The sections were then incubated with mouse monoclonal anti-CD44 antibody (catalog no: sc-7297, Santa Cruz Biotechnology, Inc., Texas 75220 USA, 1: 100) and Mouse monoclonal anti-IL-10 antibody (catalog no: ab34843, Abcam, Cambridge, MA 02139-1517, USA, 1:100) overnight at $+4^{\circ} \mathrm{C}$. The next day, sections were cleaned with PBS and secondary antibody solution (Biotinylated Goat Anti-Mouse, Lab Vision) was applied for 14 minutes. Following PBS, streptavidin peroxidase solution (Streptavidin Peroxidase, Lab Vision) was performed for 15 minutes. Slides were washed 3 times in PBS and DAB chromogen solution were applied for $8 \mathrm{~min}$. Sections were washed with distilled water and counter stained with 2 min Mayer hematoxylin. Slides were imaged with imager A2 Zeiss light microscope.

Semiquantitative scaling of sinsistial knot, congestion in blood vessels,fibrinoid acumulation nflamation and degeneration in decidua were carried out. The intensity of these changes were graded from 0 to 4 (0: no change, 1: low, 2: moderate, 3: intense 4;most intense). Semiquantitative scaling of immunoreactivity was carried out. The intensity of staining was graded from 0 to 4 (0: no staining, 1: faint staining, 2: moderate staining, 3: intense staining, 4;most intense staining).

\section{Statistical Analysis}

Statistical calculations R version 3.2.3 (2015-12-10), Copyright (C) 2015 The R Foundation for Statistical Computing free software was used in the computer package program. Student $t$ and Mann-Whitney $U$ tests were used for statistical analysis. Statistical evaluations for $p<0.05$ were considered significant.

\section{RESULTS}

Independent Samples Test evaluation results, frequency values of categorical variables, Fisher's Exact Test calculations and statistical significance values were given in the tables below and statistical histopathological evaluation was evaluated according to these data. Histopathologic scoring and immunohistochemical expression $\mathrm{p}$ values are shown in the Table 1.

The characteristics of normotensive and preeclampsia patients are shown in Table 1. The placentas of the control and preeclampsia groups were compared histologically. CD44 and IL-10 expressions were also analyzed. Clinical results of normal pregnancy and preeclampsia pregnancy were compared (Fig. 1-4). 
Table 1. Independent Sample T-test result of parameters

\section{Group Statistics}

\begin{tabular}{|c|c|c|c|c|c|}
\hline \multicolumn{2}{|l|}{ Groups } & $\mathbf{N}$ & Mean & $\begin{array}{l}\text { Std. Error } \\
\text { Mean }\end{array}$ & p value \\
\hline \multirow{2}{*}{ Age } & Control & 15 & 28.20 & 1.72 & \multirow{2}{*}{$>0.05$} \\
\hline & Preeclampsia & 15 & 31.40 & 2.74 & \\
\hline \multirow{2}{*}{ Gravida } & Control & 15 & 2.53 & 0.59 & \multirow{2}{*}{$>0.05$} \\
\hline & Preeclampsia & 15 & 3.60 & 0.76 & \\
\hline \multirow{2}{*}{ Parite } & Control & 15 & 1.07 & 0.42 & \multirow{2}{*}{$>0.05$} \\
\hline & Preeclampsia & 15 & 2.13 & 0.58 & \\
\hline \multirow{2}{*}{ TAsist } & Control & 15 & 113.00 & 2.65 & \multirow{2}{*}{$=0.00$} \\
\hline & Preeclampsia & 15 & 154.20 & 4.32 & \\
\hline \multirow{2}{*}{ TAdiast } & Control & 15 & 71.53 & 1.75 & \multirow{2}{*}{$=0.00$} \\
\hline & Preeclampsia & 15 & 96.33 & 1.45 & \\
\hline \multirow{2}{*}{ Hemoglobin } & Control & 15 & 12.19 & 0.40 & \multirow{2}{*}{$<0.05$} \\
\hline & Preeclampsia & 15 & 10.95 & 0.44 & \\
\hline \multirow{2}{*}{ Platelet } & Control & 15 & 258.33 & 18.32 & \multirow{2}{*}{$>0.05$} \\
\hline & Preeclampsia & 15 & 278.60 & 25.60 & \\
\hline \multirow{2}{*}{ Glucose } & Control & 15 & 78.87 & 2.73 & \multirow{2}{*}{$>0.05$} \\
\hline & Preeclampsia & 15 & 75.54 & 3.31 & \\
\hline \multirow{2}{*}{ Urea } & Control & 15 & 16.06 & 1.04 & \multirow{2}{*}{$>0.05$} \\
\hline & Preeclampsia & 15 & 18.28 & 1.60 & \\
\hline \multirow{2}{*}{ Kreatinin } & Control & 15 & 0.59 & 0.01 & \multirow{2}{*}{$>0.05$} \\
\hline & Preeclampsia & 15 & 0.58 & 0.02 & \\
\hline \multirow{2}{*}{ ALT } & Control & 15 & 11.07 & 1.33 & \multirow{2}{*}{$>0.05$} \\
\hline & Preeclampsia & 15 & 19.40 & 5.27 & \\
\hline \multirow{2}{*}{ AST } & Control & 15 & 22.07 & 2.98 & \multirow{2}{*}{$>0.05$} \\
\hline & Preeclampsia & 15 & 27.07 & 6.90 & \\
\hline \multirow{2}{*}{ Urine Protein } & Control & 15 & 143.27 & 7.82 & \multirow{2}{*}{$=0.00$} \\
\hline & Preeclampsia & 15 & 848.13 & 129.30 & \\
\hline
\end{tabular}

Statistically $p<0.05$ means, significantly difference between groups

\section{Histopathological Analysis}

In placentas of control group, there were slightly enlarged medium-sized blood vessels large chorionic villi, regular syncytial cells with small fibrinoid structures and knots. The collagen fibers were organized in parallel and thin bands. Small villi structures in the intervillous area were normal (Fig. 4A). The chorionic villi of the preeclamptic placenta showed syncytial node, syncytial edema, and increased collagen fiber increase. In addition, heterochromatin appearance in syncytial bridges, degenerative changes in large nuclei, dilated and congested blood vessels and inflammation outside the vessels were observed (Fig. 4B).

High CD44 expression was observed in vascular basal membrane of cytotrophoblast and fibroblast cells in preeclampsia group. CD44 activity in the control group sections showed mild positive CD44 expression in the maternal decidua cells and fibroblast cells close to the root villi. Negative CD44 expression was observed in muscle cells around the blood vessels, mucous connective tissue areas, and syncytial cells (Fig. 5A).

Preeclampsia group: Increased CD44 positive expression was observed in maternal decidua cells and fibroblast cells close to root villi. CD44 was positively expressed in muscle cells around the blood vessels, mucosal connective tissue areas, syncytial nodes and syncytial bridges (Fig. 5B). Control group: IL-10 expression in trophoblast cells and connective tissue cells in floating villi was negative while it was positive in macrophage cells, syncytial nodes and bridges of root villi (Fig. 5C).

Preeclampsia group: Significant increased IL-10 expression was seen in sub endothelial layers of the medium-sized vessels in the maternal region. IL-10 was also positively expressed in decidua cells outside the vessels and inflamed connective tissue areas, chorionic villus cells with intense inflammation in intervillous spaces (Fig. 5D).

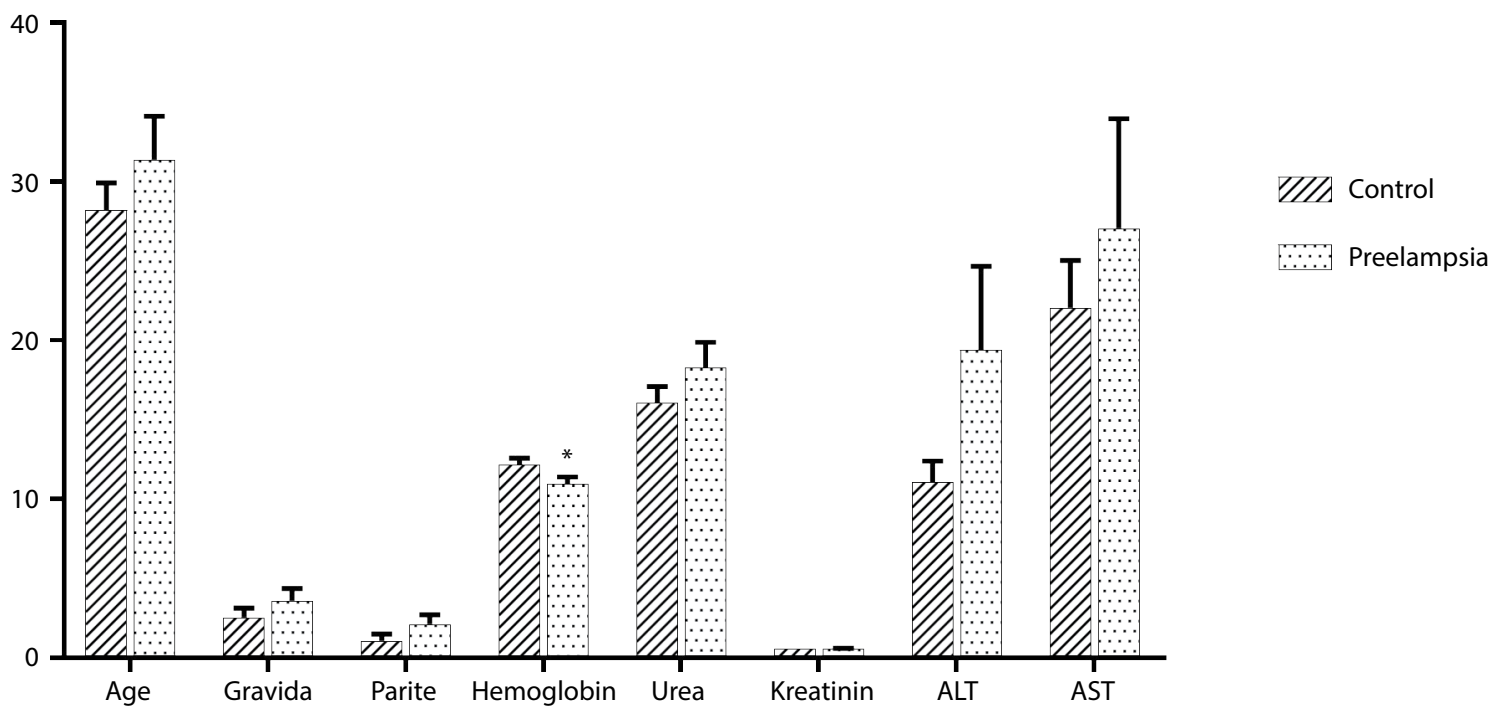

Figure 1. Independent samples T-test results of variables; Age, Gravia, Parite, Hemoglobin, Urea, Kreatinin, ALT and AST/ Different upper symbols of each column shows significantly difference between groups. $\left({ }^{*} \mathrm{p}<0.05\right)$ 


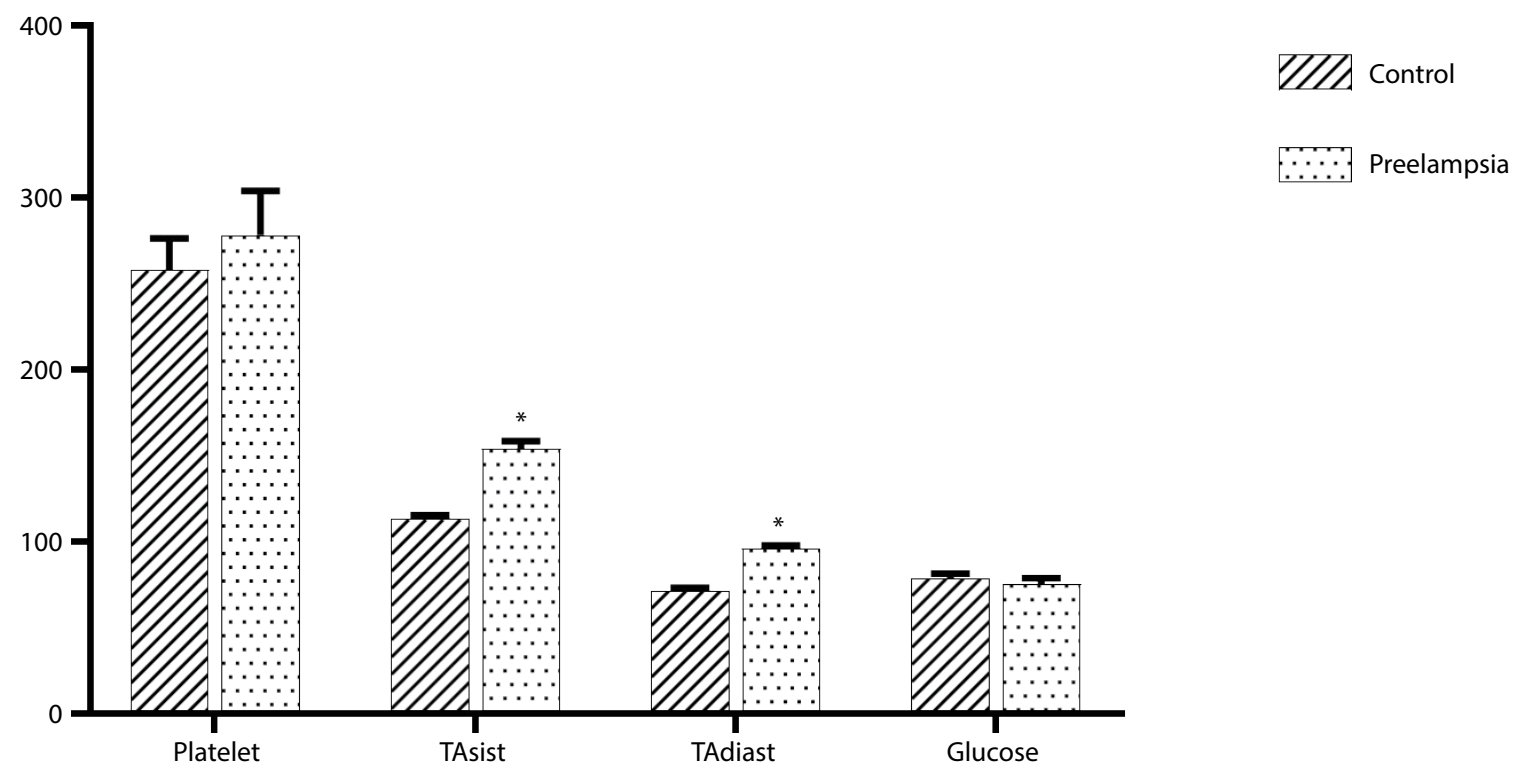

Figure 2. Independent samples T-test results of variables; Platelet, TAsist, TAdiast and glucose. Different upper symbols of each column shows significantly difference between groups. $\left({ }^{*} p=0.00\right)$

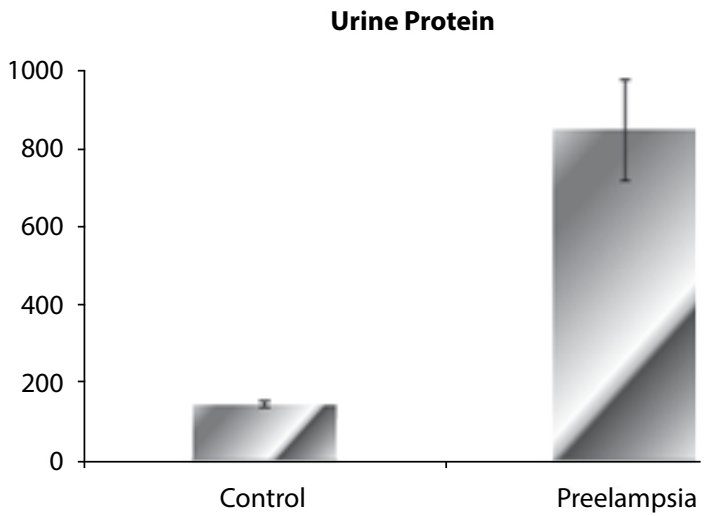

Figure 3. Independent samples T-test result of Urine. Different upper symbols of each column shows significantly difference between groups

\section{DISCUSSION}

Preeclampsia (PE) is a pregnancy complication, which is the leading cause of maternal and fetal morbidity and mortality and occurs after 20 weeks of gestation. PE is a multisystem disease accompanied by hypertension and proteinuria ( $\geq 300 \mathrm{mg} / 24 \mathrm{~h}$ ) or other symptoms (cerebral and vision symptoms, pulmonary edema, elevated serum creatinine levels, decreased platelet count $[14,15]$. If systolic blood pressure is $160 \mathrm{mmHg}$ or more and the diastolic blood pressure is $110 \mathrm{mmHg}$ or more, it is defined as severe preeclampsia [15].

Hypoxia plays an important role in preeclampsia which is a pregnancy-specific syndrome characterized by maternal hypertension and proteinuria. Normally, the transformation of maternal spiral arteries occurs during placental development in the first weeks of pregnancy and this transformation is impaired in preeclampsia resulting in reduction of placental perfusion that triggers the inflammatory response. Starting by the second trimester of pregnancy, this inflammatory response elicits classic symptoms and findings in the diagnosis of preeclampsia. Systemic vasoconstriction and hypertension develop due to damage to the endothelial area of the vessels in the maternal circulation [16-19]. Hemolysis occurs because of systemic capillary endothelial damage, elevated liver enzymes and thrombocytopenia are together defined as HELLP Syndrome $[17,19]$. Because of invasion of spiral trophoblast migration in $\mathrm{PE}$, recurrent spiral arteries of the uterus may be impaired $[20,21]$.

Decidua arteriopathy results in a decrease in blood flow to the placental villi and distal villous hypoplasia. In the preeclampsia group of our study, chorionic villus syncytial node, syncytial edema, increased collagen fiber, heterochromatin appearance in syncytial bridges and degenerative changes in large nuclei were observed. In addition, dilatation and congestion in the blood vessels, inflammation around the vessels, showed the pathological condition resulting from hypoxia.

CD44 angiogenesis, resulting in endothelial cell proliferation, migration and differentiation, may contribute to synergistic stimulation. Immunohistochemical analysis has shown that endothelial cells, basement membrane and fibroblast cells express high CD44 levels. The role of CD44/hyaluronic acid interaction reported to be important for the differentiation of endothelial cells during angiogenesis [22]. Rui Zhu et al. [23] showed expression and function of hyaluronic acid/CD44 of 


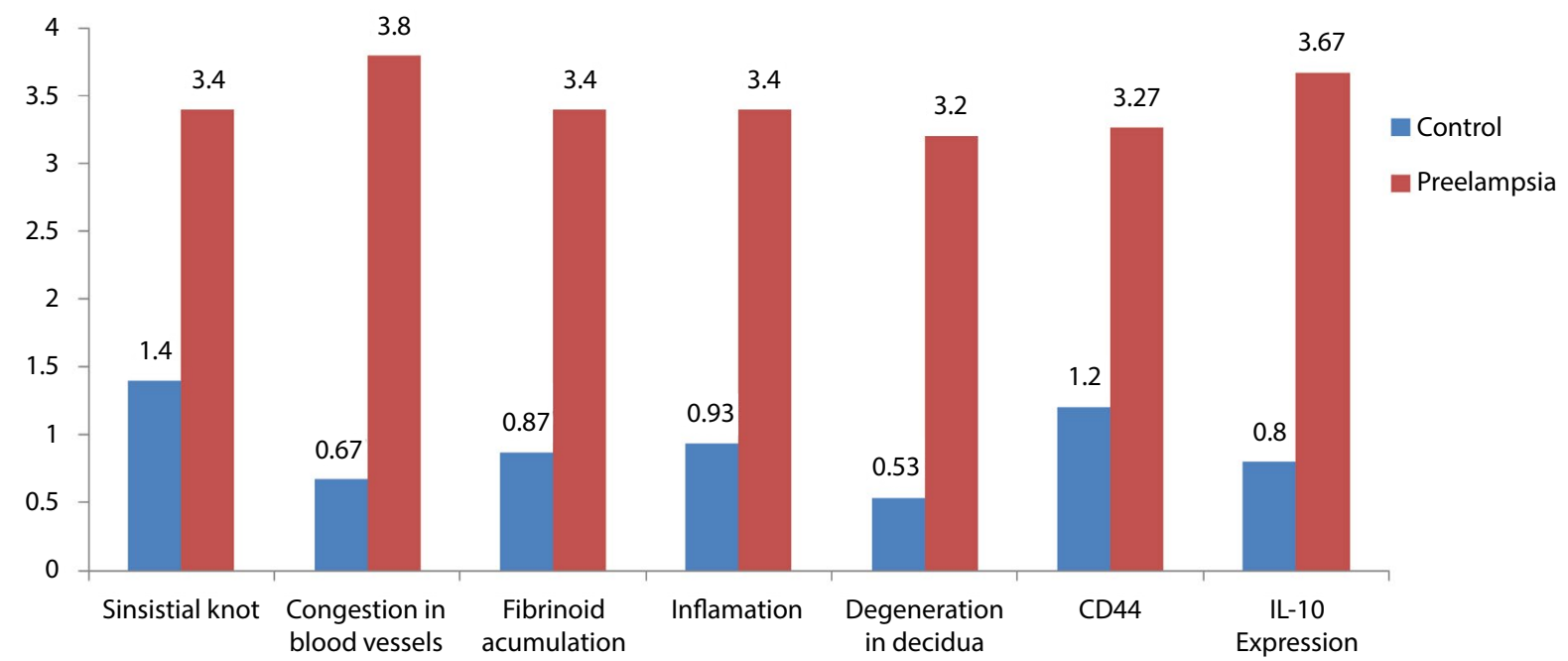

Figure 4. Graphical view of histopathological and immunohistochemical analyzes

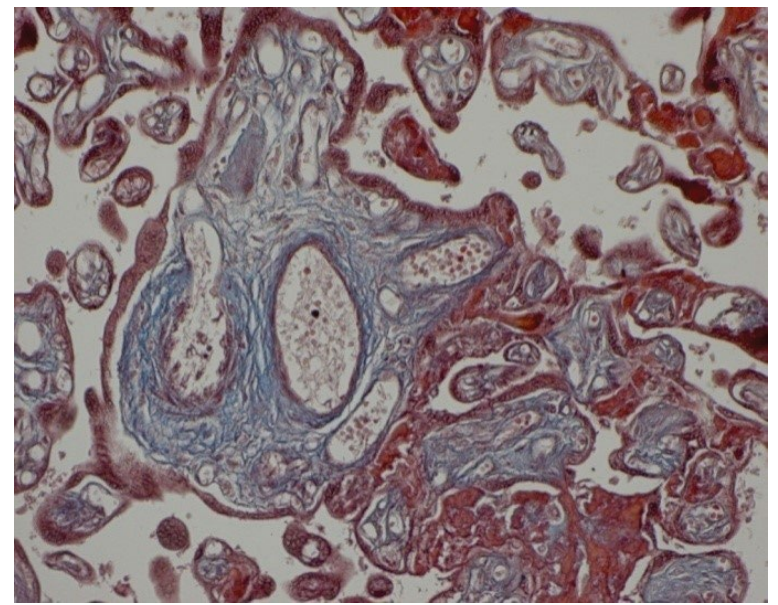

Figure 4A. Normotansive group: Trichrom-Masson stainingX40 Immunohistochemical analysis

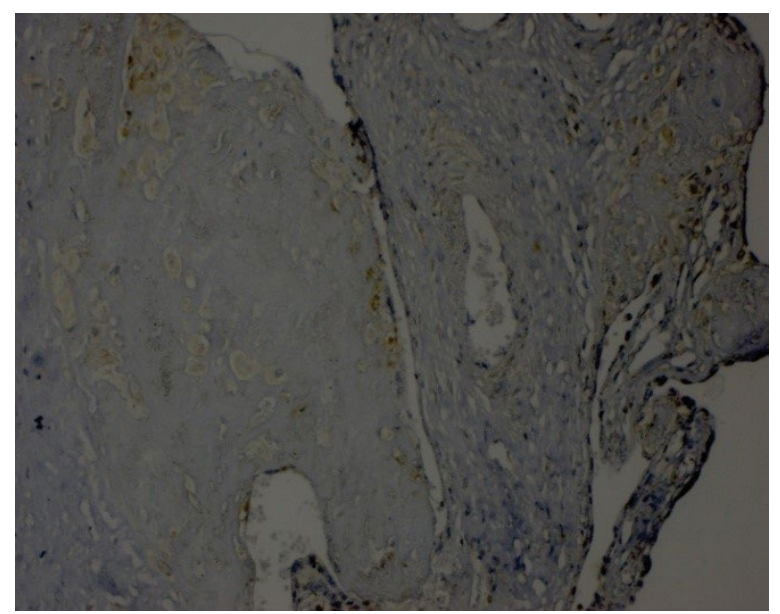

Figure 5A. Normotansive group: CD44 immunstaining Bar 50 $\mu \mathrm{m}$

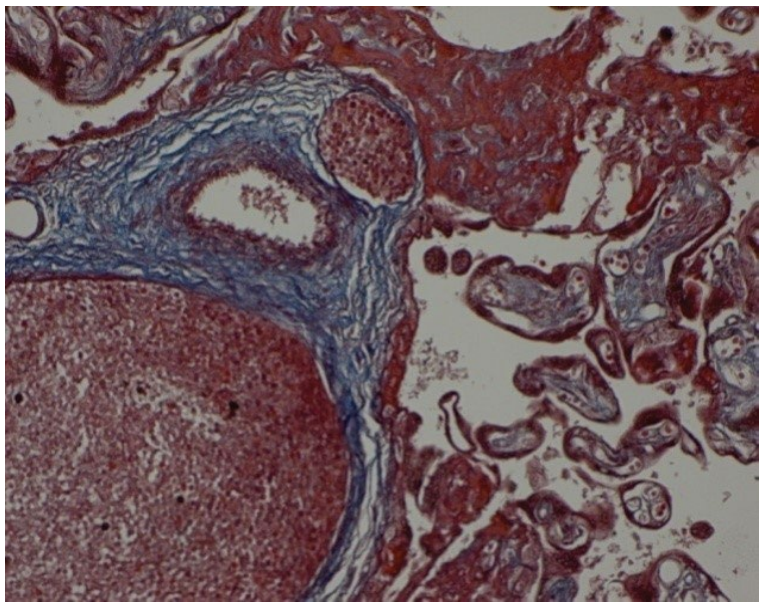

Figure 4B. Preeclampsia group Trichrom-Masson stainingX40

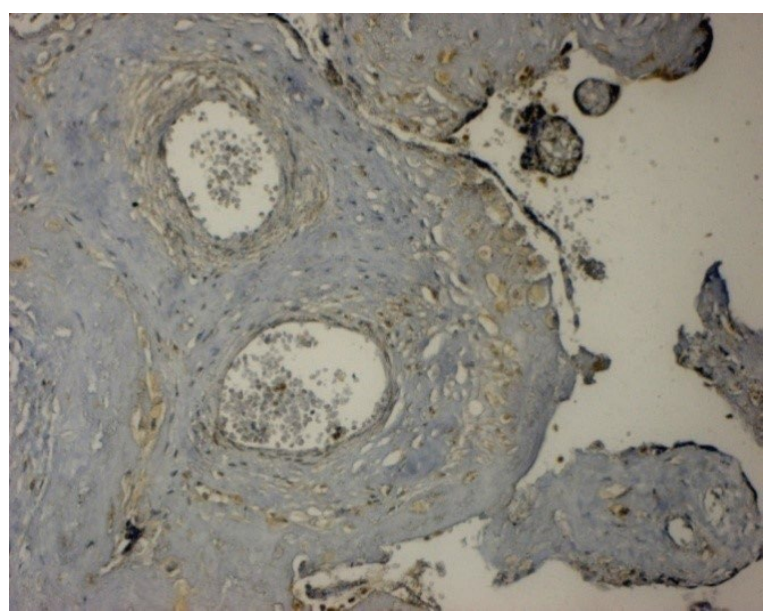

Figure 5B. Preeclampsia group CD44 immunstaining Bar 50 $\mathrm{m}$ 


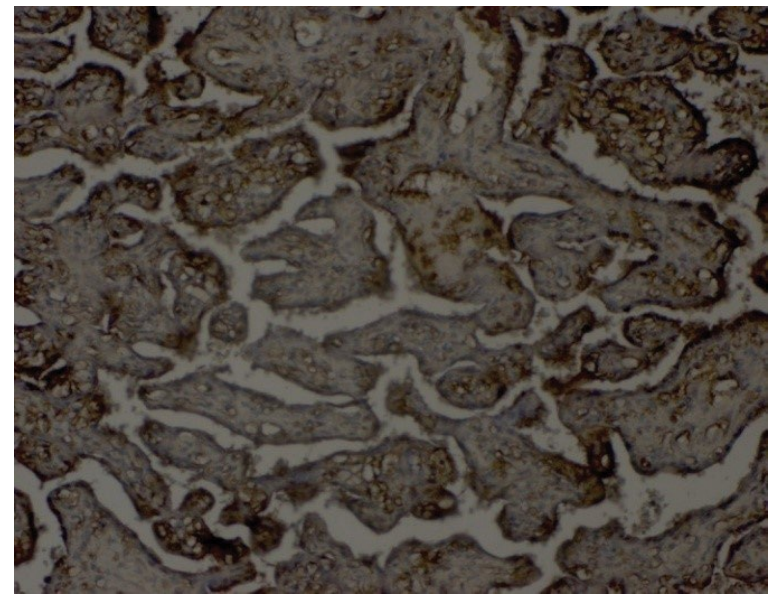

Figure 5C. Normotansive group: IL-10 immunstaining Bar 50 $\mu \mathrm{m}$

\begin{tabular}{|c|c|c|c|c|c|}
\hline \multicolumn{2}{|l|}{ Groups } & \multirow{3}{*}{$\begin{array}{l}n \\
15 \\
15\end{array}$} & \multirow{3}{*}{$\begin{array}{l}\text { Mean } \\
1.40 \\
3.40\end{array}$} & \multirow{3}{*}{$\begin{array}{l}\text { Std. } \\
\text { Error } \\
0.13 \\
0.13\end{array}$} & \multirow{3}{*}{$\begin{array}{l}\text { p value } \\
=0.000\end{array}$} \\
\hline \multirow{2}{*}{ Sinsistial knot } & Control & & & & \\
\hline & Preeclampsia & & & & \\
\hline \multirow{2}{*}{$\begin{array}{l}\text { Congestion in } \\
\text { blood vessels }\end{array}$} & Control & 15 & 0.67 & 0.48 & \multirow{2}{*}{$=0.000$} \\
\hline & Preeclampsia & 15 & 3.80 & 0.41 & \\
\hline \multirow{2}{*}{$\begin{array}{l}\text { Fibrinoid } \\
\text { acumulation }\end{array}$} & Control & 15 & 0.87 & 0.51 & \multirow{2}{*}{$=0.000$} \\
\hline & Preeclampsia & 15 & 3.40 & 0.63 & \\
\hline \multirow{2}{*}{ Inflamation } & Control & 15 & 0.93 & 0.59 & \multirow{2}{*}{$=0.000$} \\
\hline & Preeclampsia & 15 & 3.40 & 0.63 & \\
\hline \multirow{2}{*}{$\begin{array}{l}\text { Degeneration in } \\
\text { decidua }\end{array}$} & Control & 15 & 0.53 & 0.51 & \multirow{2}{*}{$=0.000$} \\
\hline & Preeclampsia & 15 & 3.20 & 0.56 & \\
\hline \multirow{2}{*}{ CD44 } & Control & 15 & 1.20 & 0.77 & \multirow{2}{*}{$=0.000$} \\
\hline & Preeclampsia & 15 & 3.27 & 0.45 & \\
\hline \multirow{2}{*}{ IL-10 Expression } & Control & 15 & 0.80 & 0.56 & \multirow{2}{*}{$=0.000$} \\
\hline & Preeclampsia & 15 & 3.67 & 0.61 & \\
\hline
\end{tabular}

Mann-Whitney U test result of parameters; statistically $\mathrm{p}<0.05$ means, significantly difference between groups

human decidua stromal cells in the first trimester of pregnancy. They reported Hyaluronic acid (HA) stimulate proliferation and growth of decidua stromal cells by autocrine signaling, high levels of $\mathrm{HA}$ provide maintenance of normal pregnancy while low content and degradation of HA may cause early pregnancy loss.The presence of a functional CD44 molecule in the human placenta plays a role in the stabilization and orientation of the HA network, which is important in maintaining the placental structural integrity for CD44 [24]. CD44 is the main cell surface receptor for hyaluronic acid (HA), an integral component of the extracellular matrix and expressed in different cell types including epithelial, mesenchymal and

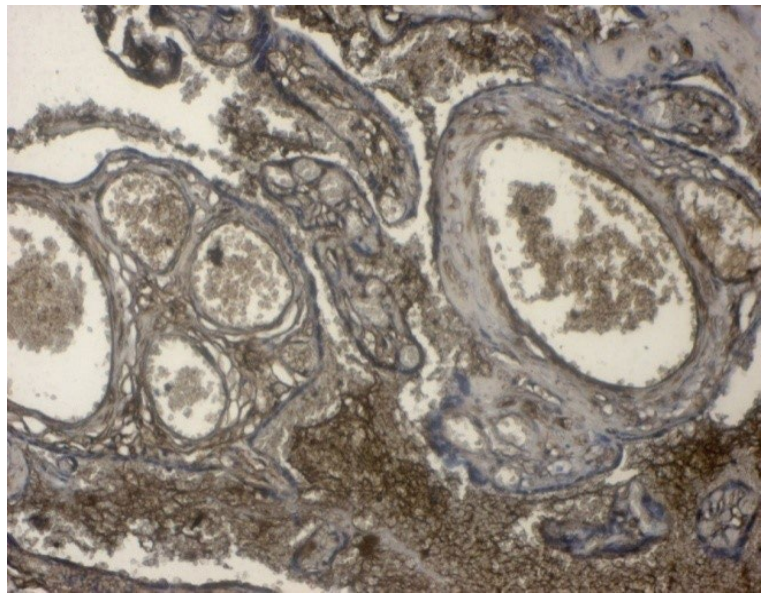

Figure 5D. Preeclampsia group IL-10 immunstaining Bar 50 $\mathrm{mm}$

hematopoietic cells, as well as immune cells. CD44 expression increases during inflammation and its variants of CD $44 \mathrm{v} 3$ and CD44 v6 are also upregulated. CD44 was reported to participate in T cell activation, migration, and cell adhesion to $\mathrm{HA}$ during the immune response [25].

A study showed that in the presence or absence of placental pathology, hyaluronic acid was a key glycan in the regulation and distribution of other hyaluronic acids the organization and stabilization of extracellular matrix and glycocalyx, in the distribution of tissues, as well as $\mathrm{HA}$ fragments with different molecular weights interact with different types of CD44 receptors. HA negatively regulates the vascular permeability by activating signaling pathways associated with the formation of the cortical layer of actin microfilaments and intracellular contacts. It positively induces vascular permeability by triggering activation of the protease-activated receptor (PAR), thereby promoting the formation of actin stress fibrils and disruption of contact between cells $[26,27]$. In our study, CD44 expression was observed in the maternal decidua cells, fibroblast cells close to the root villi, muscle cells around the blood vessels and mucosal connective tissue. In addition, the positive expression in the syncytial knots and bridges was thought to be important in altering the placental tissue structure of the secreting cells. Because HA regulates the systemic inflammatory response, different molecular weight hyaluronic acids have been reported to have various effects on pregnancy and may even promote pathology. According to the pathogenesis of $\mathrm{PE}$, the main clinical manifestations of the disease are associated with insufficient localization, excessive systemic inflammatory response and endothelial dysfunction [28]. The role of cytokines in the pathogenesis of $P E$ is important. Cytokines have many regulatory effects on interaction, uptake, activation, stimulation, killing and suppression of immune and non-immune cells. Cytokines 
were reported to be involved in various events such as ovulation, implantation, placement and delivery during pregnancy. Cytokines such as TNFa stimulate the binding of CD44 expressed on peripheral monocytes to HA and CD44 expression, and adhesion to HA in hematopoietic cells is altered as a function of the cell activation stage [29].

Cytokines such as granulocyte-macrophage colony stimulating factor (GM-CSF), colony-stimulating factor-1, IL-3 and IL-10 contribute to the success of pregnancy [30]. In the first and second trimester placental tissues, IL-10 levels were moderate and higher in the third trimester period. Decidua cells, trophoblast cells and maternal uterine lymphocyte subgroups expresses IL-10 [31]. Abnormalities in IL10 production may alter trophoblast invasion to uterus. It is proposed that Human Leukocyte Antigen-G (HLA-G), an antigen expressed by trophoblast, may regulate decidua cells expression and thus protecting maternal-fetal tolerance network. It is also emphasized that the role of inflammation is important for successful pregnancies. Chronic inflammation and lack of dissolution of anti-inflammatory cytokine producing cells can lead to various pregnancy disorders due to multiple factors. IL-4 and IL-10 play an important role in the successful pregnancy, and a deficiency of them was reported to contribute to infertility, spontaneous abortion and hypertensive pregnancy disorders [32]. The evaluation of placental tissue and serum samples from preeclamptic women showed that IL-10 production decreased. Endovascular interactions between trophoblasts and endothelial cells was reported to be impaired [33, 34]. In our study, there was a significant increased IL-10 expression in sub endothelial layers of medium-type blood vessel in the maternal region. Positive IL-10 expression was also found in inflamed connective tissue areas and decidua cells near the vessels. In addition, IL-10 activity increased in chorionic villus cells and intervillous spaces with intense inflammation.

\section{CONCLUSIONS}

In conclusion, CD44 has been found to be an important molecule in regulation of vascular permeability, inflammatory response, and in activation of the cells and the cell-to-cell interaction and the signaling pathways to which they are associated. In a study, tumor necrosis factor (TNF)-a and interleukin (IL)-10 was studied as modulator on CD44 expression in Langerhans cells. They reported that 1) TNF-a significantly upregulates CD44 expression in a concentration-dependent manner and 2) IL-10 downregulates CD44 expression in a concentration-dependent manner. IL-10, a key regulator of immune system, not only has immunomodulatory activity, but also provides direct benefit to vasculature and promotes successful cellular interactions at the fetal-maternal interface. We thought that IL-10 act like TNF-a by upregulating CD44 expression. Thus, we speculate that IL-10 is important factor in blood cells and their activation by inducing $\mathrm{HA}$ to bind CD44.

\section{REFERENCES}

1. Brown HL, Small MJ. Overview of maternal mortality and morbidity updated: Jan 2018. Erişim: 13 Mart 2018.

2. Chaiworapongsa T, Chaemsaithong $\mathrm{P}$, Yeo L, et al. Pre-eclampsia part 1: current understanding of its pathophysiology. Nat Rev Nephrol. 2014; 10(8): 466-480, doi: 10.1038/nrneph.2014.102, indexed in Pubmed: 25003615.

3. Gathiram P, Moodley J. Pre-eclampsia: its pathogenesis and pathophysiolgy. Cardiovasc J Afr. 2016; 27(2): 71-78, doi: 10.5830/CVJA-2016-009, indexed in Pubmed: 27213853.

4. Patel A, Dash PR. Formation of atypical podosomes in extravillous trophoblasts regulates extracellular matrix degradation. Eur J Cell Biol. 2012; 91(3): 171-179, doi: 10.1016/j.ejcb.2011.11.006, indexed in Pubmed: 22284833.

5. Lyall F, Robson SC, Bulmer JN. Spiral artery remodeling and trophoblast invasion in preeclampsia and fetal growth restriction: relationship to clinical outcome. Hypertension. 2013; 62(6): 1046-1054, doi: 10.1161/HYPERTENSIONAHA.113.01892, indexed in Pubmed: 24060885.

6. Madazli R, Budak E, Calay Z, et al. Correlation between placental bed biopsy findings, vascular cell adhesion molecule and fibronectin levels in pre-eclampsia. BJOG. 2000; 107(4): 514-518, doi: 10.1111/j.14710528.2000.tb13271.x, indexed in Pubmed: 10759271.

7. Toole B. Hyaluronan: from extracellular glue to pericellular cue. Nature Reviews Cancer. 2004; 4(7): 528-539, doi: 10.1038/nrc1391.

8. Vikesaa J, Hansen TVO, Jønson L, et al. RNA-binding IMPs promote cell adhesion and invadopodia formation. EMBO J. 2006; 25(7): 1456-1468, doi: 10.1038/sj.emboj.7601039, indexed in Pubmed: 16541107.

9. Roth I, Corry DB, Locksley RM, et al. FisherHuman placental cytotrophoblasts produce the immunosuppressive cytokine interleukin. J Exp Med. 1996; 184: 539-548.

10. HEIKKINEN J, MOTTONEN M, KOMI J, et al. Phenotypic characterization of human decidual macrophages. Clin Exp Immunol. 2003; 131 (3):498-505, doi: 10.1046/j.1365-2249.2003.02092.x.

11. Lidstrom C, Matthiesen L, Berg G, et al. Cytokine secretion patterns of NK cells and macrophages in early human pregnancy decidua and blood implications for suppressor macrophages in decidua. Am J Reprod Immunol. 2003; 50: 444-452.

12. Hanna N, Hanna I, Hleb M, et al. Gestational age-dependent expression of IL-10 and its receptor in human placental tissues and isolated cytotrophoblasts. J Immunol. 2000; 164: 5721-5728.

13. Chaouat G, Cayol V, Mairovitz V, et al. Localization of the Th2 cytokines IL-3, IL-4, IL-10 at the fetomaternal interface during human and murine pregnancy and lack of requirement for Fas/Fas ligand interaction for a successful allogeneic pregnancy. Am J Reprod Immunol. 1999; 42: 1-13.

14. American College of Obstetricians and Gynecologists. Hypertension in Pregnancy. Obstet Gynecol. 2013; 122: 1122-1131.

15. Steegers E, Dadelszen Pv, Duvekot J, et al. Pre-eclampsia. Lancet. 2010; 376(9741): 631-644, doi: 10.1016/s0140-6736(10)60279-6.

16. Şencan İ, Engin-Üstün Y, Sanisoğlu S. 2014 yılı Türkiye ulusal anne ölümlerinin demografi k verilere göre değerlendirilmesi. J Gynecol Obstet Neonatal. 2016; 13: 45.

17. Peres GM, Mariana M, Cairrão E. Pre-Eclampsia and Eclampsia: An Update on the Pharmacological Treatment Applied in Portugal. J Cardiovasc Dev Dis. 2018;5(1), doi: 10.3390/jcdd5010003, indexed in Pubmed: 29367581.

18. Sava RI, March KL, Pepine CJ. Hypertension in pregnancy: Taking cues from pathophysiology for clinical practice. Clin Cardiol. 2018; 41(2): 220-227, doi: 10.1002/clc.22892, indexed in Pubmed: 29485737.

19. Çelik N, Saruhan A. Gebelikte riskli durumlar. In: Sevil Ü, Ertem G. ed. Perinataloji ve bakım. Ankara Nobel Tıp Kitabevleri, Ankara 2016: 231-246.

20. Walentin $\mathrm{K}$, Hinze $\mathrm{C}$, Schmidt-Ott KM. The basal chorionic trophoblast cell layer: An emerging coordinator of placenta development. Bioessays. 2016; 38(3): 254-265, doi: 10.1002/bies.201500087, indexed in Pubmed: 26778584

21. ChaiworapongsaT, Chaemsaithong $\mathrm{P}, \mathrm{Yeo} \mathrm{L}$, et al. Pre-eclampsia part 1 : current understanding of its pathophysiology. Nat Rev Nephrol. 2014; 10(8): 466-480, doi: 10.1038/nrneph.2014.102, indexed in Pubmed: 25003615.

22. Balsak D, Togrul $C$, Ekinci $C$, et al. Severe pre-eclampsia complicated by HELLP syndrome alterations in the structure of the umbilical cord (morphometric and immunohistochemical study). Biotechnol Biotechnol Equip. 2015; 29(2): 345-350, doi: 10.1080/13102818.2014.991545, indexed in Pubmed: 26019650. 
23. Zhu R, Wang SC, Sun C, et al. Hyaluronan-CD44 interaction promotes growth of decidual stromal cells in human first-trimester pregnancy. PLoS One. 2013; 8(9): e74812, doi: 10.1371/journal.pone.0074812, indexed in Pubmed: 24069351.

24. Jacques S, Dadi H, Letarte M. CD44 in human placenta: Localization and binding to hyaluronic acid. Placenta. 1993; 14(1): 25-39, doi: 10.1016/s0143-4004(05)80246-2.

25. Thapa R, Wilson GD. The Importance of CD44 as a Stem Cell Biomarker and Therapeutic Target in Cancer. Stem Cells Int. 2016; 2016: 2087204, doi: 10.1155/2016/2087204, indexed in Pubmed: 27200096.

26. Mambetsariev N, Mirzapoiazova T, Mambetsariev B, et al. Hyaluronic Acid binding protein 2 is a novel regulator of vascular integrity. Arterioscler Thromb Vasc Biol. 2010; 30(3): 483-490, doi: 10.1161/ATVBAHA.109.200451, indexed in Pubmed: 20042707.

27. Singleton PA, Dudek SM, Ma SF, et al. Transactivation of sphingosine 1-phosphate receptors is essential for vascular barrier regulation. Novel role for hyaluronan and CD44 receptor family. J Biol Chem. 2006; 281(45): 3438134393, doi: 10.1074/jbc.M603680200, indexed in Pubmed: 16963454

28. Ziganshina MM, Pavlovich SV, Bovin NV, et al. Hyaluronic Acid in Vascular and Immune Homeostasis during Normal Pregnancy and Preeclampsia. Acta Naturae. 2016; 8(3): 59-71, indexed in Pubmed: 27795844.
29. Lesley J, Hyman R, Kincade PW. CD44 and its interaction with extracellular matrix. Adv Immunol. 1993; 54: 271-335, doi: 10.1016/s00652776(08)60537-4, indexed in Pubmed: 8379464.

30. Bowen JM, Chamley L, Mitchell MD, et al. Cytokines of the placenta and extra-placental membranes: biosynthesis, secretion and roles in establishment of pregnancy in women. Placenta. 2002; 23(4): 239-256, doi: 10.1053/plac.2001.0781, indexed in Pubmed: 11969335.

31. Thaxton JE, Sharma S. Interleukin-10: a multi-faceted agent of pregnancy. Am J Reprod Immunol. 2010; 63(6): 482-491, doi: 10.1111/j.160 0-0897.2010.00810.x, indexed in Pubmed: 20163400.

32. Chatterjee $P$, Chiasson VL, Bounds KR, et al. Regulation of the anti-inflammatory cytokines interleukin-4 and interleukin-10 during pregnancy. Frontiers in Immunology |Inflammation. 2014; 5: Article 253.

33. Hennessy A, Pilmore HL, Simmons LA, et al. A deficiency of placental IL-10 in preeclampsia. J Immunol. 1999; 163(6): 3491-3495, indexed in Pubmed: 10477622.

34. Wilczyński JR, Tchórzewski H, Głowacka $E$, et al. Cytokine secretion by decidual lymphocytes in transient hypertension of pregnancy and pre-eclampsia. Mediators Inflamm. 2002; 11(2): 105-111, doi: 10.1080/09629350220131962, indexed in Pubmed: 12061422. 